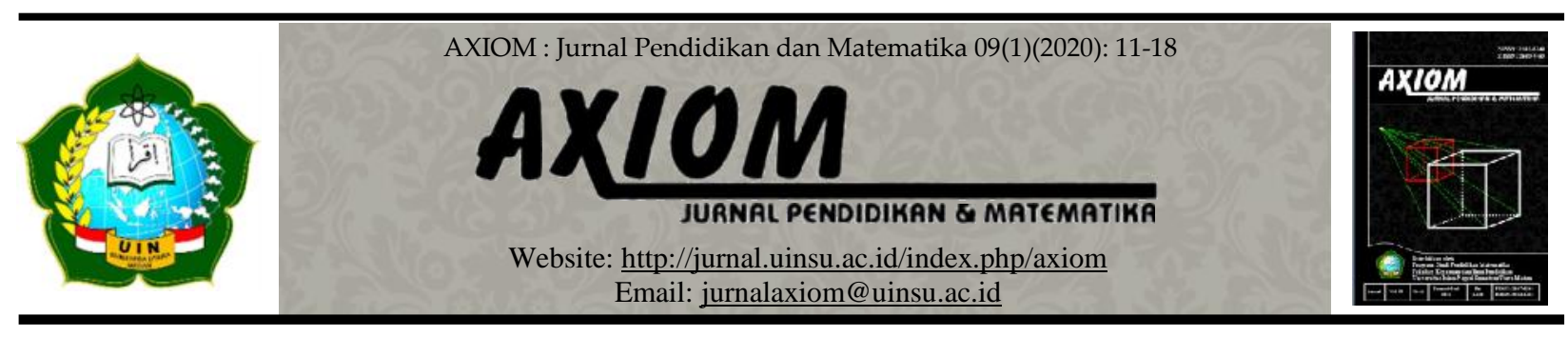

\title{
PENINGKATAN KEMAMPUAN BERPIKIR KRITIS TERHADAP PEMBELAJARAN MATEMATIKA DENGAN MODEL DISCOVERY LEARNING PADA SISWA KELAS X MAN 1 KAMPAR
}

Oleh:

\author{
Sri Ulfa Insani \\ Pendidikan Matematika Universitas Pahlawan Tuanku Tambusai \\ E-mail: sriulfainsanishelly@gmail.com
}

doi : 10.3082/axiom.v\%vi\%i.7255

\begin{abstract}
Abstrak:
Tujuan penelitian ini adalah untuk meningkatkan kemampuan berpikir kritis siswa terhadap pembelajaran matematika dengan menggunakan model discovery learning pada siswa kelas $\mathrm{X}$ MIA 1 MAN 1 Kampar. Penelitian ini merupakan penelitian tindakan kelas yang dilaksanakan sebanyak dua siklus dengan 6 kali pertemuan. Subjek penelitian adalah siswa kelas X MIA 1 yang berjumlah 34 orang siswa. Teknik pengumpulan data pada penelitian ini menggunakan teknik tes dan non tes (observasi dan dokumentasi). Instrumen yang digunakan adalah soal kemampuan berpikir kritis dan lembar observasi. Selanjutnya teknik analisis data yang digunakan adalah analisis data kualitatif terhadap observasi proses pembelajaran dan kuantitatif terhadap hasil tes kemampuan berpikir kritis. Hasil penelitian menunjukkan terdapat peningkatan kemampuan berpikir kritis siswa terhadap pembelajaran matematika. Hasil tersebut diperoleh berdasarkan hasil tes kemampuan berpikir kritis yang diberikan pada akhir siklus I dan II. Pada siklus I terdapat 20 orang yang tuntas dengan rata-rata 78.4 dan pada siklus II terdapat 27 siswa yang tuntas dengan rata-rata 83.1. Berdasarkan hasil penelitian tersebut, diperoleh kesimpulan bahwa kemampuan berpikir kritis siswa mengalami peningkatan dengan menerapkan model discovery learning pada siswa kelas X MIA 1 MAN 1 Kampar pada tahun ajaran 2018/2019.
\end{abstract}

Kata Kunci:

Discovery Learning, Kemampuan Berpikir Kritis

\section{Abstract:}

The aim of this researchis to improve student's critical thinking skills in learning mathematics by using discovery learning models in class X MIA 1 MAN 1 Kampar. This study was classroom action research conducted in two cycles with 6 meetings. Thesubjects were students of class $X$ MIA 1 with 34 students. The data collection techniques used test and non-test(observation and documentation). The research instruments were questions of critical thinking skills and observation sheets. The data analysis techniques useddata qualitative analysisbased on the observation of learning process and data quantitative analysis based on the results of critical thinking skills test. The results showed that there was an increase in student's critical thinking skills in mathematics. The results were obtained based on the results of tests of critical thinking skills given at the end of cycles I and II. In the first cycle there were 20 people who completed with an average of 77.8 and in the second cycle there were 27 students who completed an average of 83.1. Based on the results of the study, it was concluded that student's critical thinking 
skills improved by applying discovery learning models in class X MIA 1 MAN 1 Kampar in 2018/2019 school year.

\title{
Keywords:
}

\author{
Discovery Learning, Critical Thinking Skills
}

\section{A. Pendahuluan}

Pembelajaran merupakan suatu proses pengembangan potensi dan kemampuan yang dimiliki siswa. Pembelajaran sebagai proses belajar dibangun oleh guru untuk mengembangkan kreativitas peserta didik agar dapat meningkatkan kemampuan berpikir peserta didik, serta dapat meningkatkan kemampuan mengkonstruksi pengetahuan baru sebagai upaya meningkatkan penguasaan yang baik terhadap materi pembelajaran (Sagala, 2010: 62). Kemampuan tersebut meliputi sikap, pengetahuan, dan keterampilan yang diperlukan dalam kehidupan sehari-hari. Salah satu pengetahuan yang perlu dipelajari dan dipahami oleh siswa adalah matematika.

Matematika merupakan salah satu materi yang sangat penting untuk dipelajari. Hal ini dikarenakan dapat membuat siswa berpikir logis, kritis dan logis. Permendikbud Nomor 59 Tahun 2014 menyebutkan bahwa matematika merupakan ilmu universal yang berguna bagi kehidupan manusia dan juga mendasari perkembangan teknologi modern, serta mempunyai peran penting dalam berbagai disiplin dan memajukan daya pikir manusia. Matematika sebagai suatu mata pelajaran memiliki tingkat kesulitan tersendiri bagi siswa. Terlebih terhadap materi yang membutuhkan solusi penyelesaian masalah dan kemampuan berpikir kritis. Terhadap kesulitan yang dirasakan siswa tersebut, menuntut para guru untuk memaparkan dan menyajikan materi dengan baik agar mudah untuk dipahami dan dimengerti siswa.

Kemampuan berpikir kritis penting dimiliki oleh siswa, karena kemampuan berpikir kritis merupakan sebuah proses terorganisasi yang memungkinkan siswa mengevaluasi bukti, asumsi, logika dan bahasa yang mendasari pernyataan orang lain (Fitriawati, 2010: 36). Berpikir kritis juga merupakan berpikir dengan baik dan merenungkan tentang proses berpikir tersebut. Kemampuan berpikir kritis meliputi kegiatan menganalisis ide atau gagasan ke arah yang lebih spesifik, membedakannya secara tajam, memilih, mengidentifikasi, mengkaji dan mengembangkannya ke arah yang lebih sempurna (Wijaya, 2010: 72).

Kemampuan berpikir kritis merupakan hal penting dalam proses pembelajaran, namun dalam proses pembelajaran terdapat sejumlah kendala. Berdasarkan hasil observasi yang dilakukan peneliti di MAN 1 Kampar, ketika guru memberikan soal matematika berupa esai yang dirasa baru bagi siswa, siswa terlihat mengalami kesulitan dalam mengerjakan soal tersebut. Kesulitan yang dialami siswa ditunjukkan dengan siswa yang tidak bisa mengidentifikasi masalah, bingung dalam menentukan penyelesaian maupun rumus yang akan digunakan yang berdampak pada lamanya siswa dalam mengerjakan soal, dan beberapa siswa melihat hasil pekerjakan teman dan belum bisa menyimpulkan.

Kemudian berdasarkan hasil wawancara yang dilakukan dengan guru di MAN 1 Kampar mengenai kemampuan berpikir kritis siswa, diperoleh informasi bahwa ketika siswa diberikan latihan berupa soal-soal, beberapa siswa berpatokan pada contoh soal yang ada. Kemudian jika melihat soal cerita apalagi dengan teks panjang, siswa cenderung malas mengerjakan soal tersebut. Bimbingan guru sangat mendominasi agar soal-soal yang diberikan bisa terselesaikan sesuai waktu.

Terhadap permasalahan yang ada, maka dapat diterapkan suatu model pembelajaran untuk meningkatkan kemampuan berpikir kritis siswa. Salah satu model yang digunakan adalah discovery learning (penemuan terbimbing). Hal ini didukung oleh penelitian Insani (2018) dengan judul Upaya Meningkatkan Rasa Ingin Tahu Siswa Terhadap Pembelajaran Matematika melalui Model Discovery Learning dengan Pendekatan Saintifik pada Siswa Kelas X MIA 2 MAN Yogyakarta 1, yang menyebutkan bahwa rasa ingin tahu dan hasil belajar siswa meningkat dengan menerapkan model discovery learning dengan pendekatan saintifik.

Berdasarkan uraian di atas, akan dilakukan penelitian dengan menerapkan model pembelajaran discovery learning untuk meningkatkan kemampuan berpikir kritis siswa terhadap 
pembelajaran matematika. Diharapkan penggunaan model discovery learning dapat mengatasi permasalahan-permasalahan yang terjadi dalam proses pembelajaran di atas. Oleh karena itu peneliti berkolaborasi dengan guru matematika untuk melakukan penelitian dengan judul "Peningkatkan Kemampuan Berpikir Kritis Terhadap Pembelajaran Matematika dengan Model Discovery Learning pada Siswa Kelas X MAN 1 Kampar".

\section{B. Kajian Teoritis}

\section{Discovery Learning}

Sani (2014: 97) mengungkapkan bahwa discovery learning merupakan kegiatan menemukan konsep melalui serangkaian data atau informasi yang diperoleh melalui pengamatan atau percobaan. Discovery learning didefinisikan sebagai proses pembelajaran yang terjadi bila materi pembelajaran tidak disajikan dalam bentuk finalnya, tetapi diharapkan siswa mengorganisasi sendiri (Kurniasih \& Sani, 2014: 64). Melalui belajar penemuan, siswa dapat belajar berpikir analisis dan mencoba memecahkan sendiri masalah yang dihadapi.

Metode pembelajaran penemuan atau discovery learning merupakan sarana bagi siswa untuk terlibat dalam pemecahan masalah dan mengembangkan pengetahuan atau keterampilan mereka.Pembelajaran penemuan perlu direncanakan, diawasi oleh guru sebagai pembimbing jalannya proses pembelajaran, serta mengikuti langkah-langkah pembelajaran metode saintifik (Moore, 2009: 178).

Pada dasarnya apabila siswa telah menguasi konsep-konsep dan prinsip dasar dari materi yang akan dipelajari, maka siswa akan lebih mudah menguasi materi yang akan dipelajari selanjutnya, guru memberikan bantuan secukupnya selama proses pembelajaran berlangsung serta memberikan kesempatan seluas luasnya kepada siswa untuk membangun pengetahuan mereka (Gagne, 1984). Namun, siswa tidak dibiarkan begitu saja dalam menemukan sendiri konsep-konsep atau prinsip-prinsip dari suatu materi. Terkadang siswa dengan kemampuan matematika yang kurang baik akan kesulitan untuk menemukan konsep secara mandiri dan membutuhkan bantuan guru. Bantuan yang diberikan oleh guru sangat penting bagi siswa, agar siswa tetap berada dalam pengawasan dan untuk memastikan bahwa siswa memperoleh pemahaman yang baik. Berdasarkan pembahasan di atas, maka model discovery learning merupakan model pembelajaran yang membantu siswa dalam menemukan dan menyusun konsep maupun pengetahuan dengan arahan dari guru.

\section{Berpikir Kritis}

Berpikir kritis merupakan salah satu proses berpikir tingkat tinggi yang dapat digunakan dalam pembentukan sistem konseptual siswa.Menurut Suryosubroto (2009: 193) berpikir kritis merupakan proses mental untuk menganalisis informasi yang diperoleh. Informasi tersebut didapatkan melalui pengamatan, pengalaman, komunikasi, atau membaca.Dalam berpikir kritis terdapat sebuah proses sistematis yang memungkinkan siswa untuk merumuskan dan mengevaluasi keyakinan pendapat mereka sendiri. Hal tersebut senada dengan pendapat John Chaffe (dalam Elaine, 2010: 187) yang menyatakan berpikir kritis didefinisikan sebagai berpikir untuk menyelidiki secara sistematis proses berpikir itu sendiri. Maksudnya tidak hanyamemikirkan dengan sengaja, tetapi juga meneliti bagaimana kita dan orang lain menggunakan bukti dan logika.

Santrock (2011: 359) menambahkan bahwa pemikiran kritis adalah pemikiran reflektif danproduktif, sertamelibatkan evaluasi bukti.Kemampuan berpikir kritis sangat diperlukan untuk menganalisis suatu permasalahan hingga pada tahap pencarian solusi untuk menyelesaikan permasalahan tersebut. Seseorang yang memiliki kemampuan berpikir kritis akan mencoba untuk memperoleh banyak jawaban atau mencoba mengembangkankemungkinan jawaban lain berdasarkan analisis dan informasi yang telah didapat dari suatu permasalahan.

Berdasarkan pendapat para ahli, dapat disimpulkan bahwa kemampuan berpikir kritis merupakan kemampuan yang dimiliki setiap orang untuk menganalisis, menemukan bukti, menyelesaikan masalah dan melakukan evaluasi. 


\section{Metode Penelitian}

\section{Desain Penelitian Tindakan}

Desain penelitian ini adalah Penelitian Tindakan Kelas (PTK). Menurut Arikunto (2006: 58) penelitian tindakan kelas adalah penelitian tindakan yang dilakukan di kelas dengan tujuan memperbaiki/meningkatkan mutu praktik pembelajaran. Tiap siklus diawali dengan perencanaan, pelaksanaan, pengamatan dan refleksi seperti gambar berikut ini.

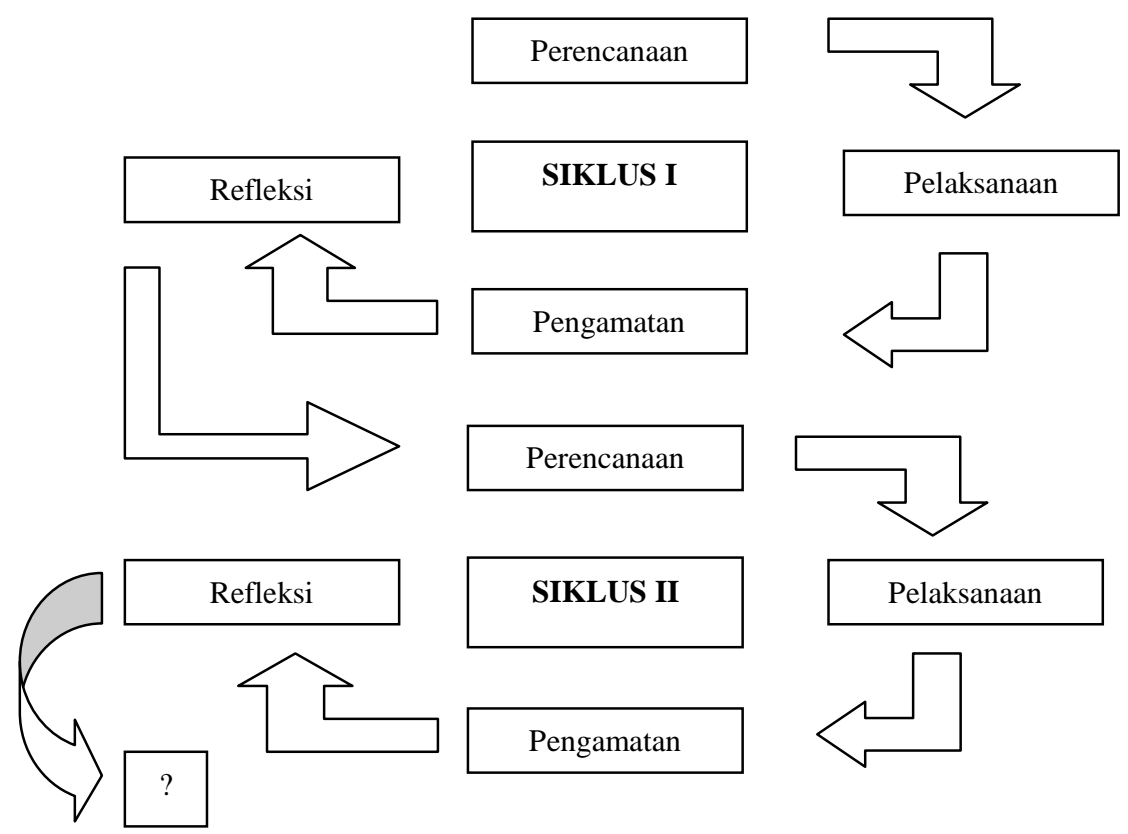

Gambar 1. Siklus Penelitian Tindakan Kelas

Sumber: Arikunto (2006: 16)

\section{Waktu dan Tempat Penelitian}

Penelitian ini dilaksanakan di kelas X MIA 1 MAN 1 Kampar sebanyak 2 siklus dengan 6 kali pertemuan. Penelitian dilaksanakan pada semester genap tahun ajaran 2018/2019.

\section{Subjek Penelitian}

Subjek penelitian ini adalah siswa kelas X MIA 1 MAN 1 Kampar yang berjumlah 34 orang yang terdiri dari 19 siswa laki-laki dan 15 siswa perempuan.

\section{Prosedur Penelitian}

\section{Siklus I}

a. Perencanaan

Adapun kegiatan yang dilakukan pada tahap ini meliputi:

1) Menyusun perangkat pembelajaran yang akan digunakan seperti RPP dan LKS

2) Menyusun lembar observasi pembelajaran

3) Menyusun soal kemampuan berpikir kritis beserta rubrik dan pedoman penskoran

4) Diskusi dengan guru mengenai pembelajaran yang akan dilaksanakan yaitu dengan menggunakan model discovery learning.

b. Pelaksanaan

Adapun kegiatan yang dilakukan pada tahap ini meliputi pelaksanaan kegiatan pembelajaran yang telah disusun pada RPP yaitu pembelajaran discovery learning. Adapun langkahlangkahnya adalah stimulation (stimulasi/pemberian rangsangan), problem statement (pernyataan/identifikasi masalah), data collection (pengumpulan data), data processing (pengolahan data), verification (pembuktian). 


\section{c. Pengamatan}

Selama kegiatan pembelajaran discovery learning, peneliti dibantu observer melakukan observasi. Observasi yang dilaksanakan berupa monitoring dan mendokumentasikan segala aktivitas guru dan siswa di kelas.

d. Refleksi

Pada akhir siklus dilakukan refleksi terhadap pembelajaran berdasarkan hasil kegiatan tahap pelaksanaan dan pengamatan. Hasil dari kegiatan tersebut dianalisis guna mengetahui sesuai atau tidaknya kegiatan yang direncanakan dengan yang dilaksanakan.

\section{Siklus II}

Hasil refleksi pada siklus I kemudian ditindak lanjuti dengan pelaksanaan pada siklus yang kedua. Adapun tahapan pada siklus II meliputi sebagai berikut:

a. Perencanaan

Adapun kegiatan yang dilakukan pada tahap ini sama dengan tahap perencanaan pada siklus I, yaitu: (1) menyusun perangkat pembelajaran yang akan digunakan seperti RPP dan LKS, (2) menyusun lembar observasi pembelajaran, (3) menyusun soal kemampuan berpikir kritis beserta rubrik dan pedoman penskoran

b. Pelaksanaan

Adapun kegiatan yang dilakukan pada tahap ini meliputi pelaksanaan kegiatan pembelajaran yang telah disusun pada RPP yaitu pembelajaran discovery learning. Adapun langkahlangkahnya adalah stimulation (stimulasi/pemberian rangsangan), problem statement (pernyataan/identifikasi masalah), data collection (pengumpulan data), data processing (pengolahan data), verification (pembuktian).

c. Pengamatan

Selama kegiatan pembelajaran discovery learning, peneliti dibantu observer melakukan observasi. Observasi yang dilaksanakan berupa monitoring dan mendokumentasikan segala aktivitas guru dan siswa di kelas.

d. Refleksi

Pada akhir siklus dilakukan refleksi terhadap pembelajaran berdasarkan hasil kegiatan tahap pelaksanaan dan pengamatan. Pada tahap ini peneliti membandingkan hasil pada siklus II dengan hasil pada siklus I.

\section{Data, Intrumen, dan Teknik Pengumpulan Data}

Data yang diperlukan pada penelitian ini adalah nilai berpikir kritis siswa. Adapun instrumen pengumpulan data yang digunakan adalah soal kemampuan berpikir kritis dan lembar observasi keterlaksanaan pembelajaran. Selanjutnya teknik pengumpulan data pada penelitian ini menggunakan teknik tes dan nontes. Tes yang digunakan adalah essay untuk mengukur kemampuan berpikir kritis siswa sedangkan nontes untuk observasi dan dokumentasi.

\section{Teknik Analisis Data}

Data yang sudah diperoleh melalui tes kemampuan berpikir kritisdan lembar pengamatan kemudian dianalisis. Teknik analisis data yang digunakan adalah analisis data kualitatif dan analisis data kuantitatif.

a. Teknik analisis data kualitatif

Teknik analisis data kualitatif diperoleh dari lembar pengamatan aktivitas guru dan aktivitas siswa yang diungkapkan dengan kata-kata untuk menggambarkan aktivitas yang terjadi dalam proses pembelajarandan untuk mengetahui hambatan-hambatan yang muncul dalam pelaksanaan pembelajaran. Kegiatan pembelajaran yang terlaksana diberi nilai 1 dan jika tidak terlaksana diberi nilai 0 . Skor yang diperoleh selanjutnya diubah menjadi persentase keterlaksanaan pembelajaran dengan cara: 
Persentase Keterlaksanaan $=\frac{\text { Jumlah tahapan pembelajaran yang terlaksana }}{\text { Jumlah Deseluruhan tahapan pembelajaran }} \times 100 \%$

Adapun kriteria keberhasilan tindakan sebagai berikut:

Tabel 1. Kriteria Keberhasilan Tindakan

\begin{tabular}{cc}
\hline Skor & Kriteria \\
\hline $90 \%<P \leq 100 \%$ & Sangat baik \\
$80 \%<P \leq 90 \%$ & Baik \\
$70 \%<P \leq 80 \%$ & Cukup \\
$60 \%<P \leq 70 \%$ & Kurang \\
$0 \%<P \leq 60 \%$ & Sangat kurang \\
\hline
\end{tabular}

Sumber: Sugiyono (2004: 43)

Kemampuan guru mengelola pembelajaran dikatakan efektif jika berada pada kategori minimal baik.

b. Teknik analisis data kuantitatif

Teknik analisis data kuantitatif diperoleh dari data hasil tes kemampuan berpikir kritis siswauntuk mendeskripsikan tentang efektivitas dari pembelajaran yang meliputi hasil kemampuan berpikir kritis siswa.Hasil tes siklus pertama maupun siklus lanjutan mencerminkan sejauh mana tingkat ketercapaian kompetensi siswa pada materi tertentu dan ketuntasan siswa selama proses pembelajaran. Untuk mengetahui ada atau tidaknya peningkatan nilai siswa dapat menghitung rata-rata nilai siswa dengan cara berikut:

$$
\text { Rata }- \text { rata Nilai }=\frac{\text { Jumlah Skor } \text { Keseluruhan yang diperoleh Siswa }}{\text { Jumlah Siswa }}
$$

Selanjutnya untuk mengetahui persentase ketuntasan dapat dihitung dengan cara berikut:

Persentase Ketuntasan $=\frac{\text { Jumlah Siswayang Tuntas }}{\text { Jumlah SeluruhSiswa }} \times 100 \%$

Setelah diperoleh hasil persentase kemampuan berpikirkritissiswa, peneliti menentukan kategori kemampuan berpikir kritis siswa. Pemberian kategori bertujuan untuk mengetahui kualifikasi persentase kemampuan berpikir kritis siswa yang disajikan pada tabel berikut.

Tabel 2. Kriteria Kemampuan Berpikir Kritis

$\begin{array}{cc}\text { Skor } & \text { Kriteria } \\ 89 \%<P \leq 100 \% & \text { Sangat tinggi } \\ 78 \%<P \leq 89 \% & \text { Tinggi } \\ 64 \%<P \leq 78 \% & \text { Sedang } \\ 55 \%<P \leq 64 \% & \text { Rendah } \\ 0 \%<P \leq 55 \% & \text { Sangat rendah }\end{array}$

Sumber: Slameto (1996: 189) 
Sri Ulfa Insani: Peningkatan Kemampuan Berpikir Kritis Terhadap Pembelajaran Matematika dengan Model Discovery Learning pada Siswa Kelas X MAN 1 Kampar

\section{Indikator Keberhasilan Tindakan}

Indikator keberhasilan pada penelitian ini adalah:

1. Terdapat peningkatan kemampuan berpikir kritis siswa pada tiap siklus dalam kategori minimal tinggi yaitu mulai dari rentang $78 \%<P \leq 100 \%$.

2. Keterlaksanaan aktivitas pembelajaran guru dan siswa mencapai target tergolong pada kategori minimal baik yaitu mulai dari rentang $80 \%<P \leq 100 \%$.

\section{Hasil Penelitian dan Pembahasan}

Pada akhir pertemuan tiap siklus diberikan tes berupa soal kemampuan berpikir kritis dan diperoleh data yang disajikan pada tabel 3. berikut.

Tabel 3. Hasil Kemampuan Berpikir Kritis Siswa Siklus I dan Siklus II

\begin{tabular}{|c|c|c|c|}
\hline Interval Skor & Kriteria & Akhir Siklus I & Akhir Siklus II \\
\hline $89<P \leq 100$ & Sangat tinggi & $8.82 \%$ & $26.47 \%$ \\
\hline $78<P \leq 89$ & Tinggi & $50 \%$ & $41.18 \%$ \\
\hline $64<P \leq 78$ & Sedang & $35.29 \%$ & $32.35 \%$ \\
\hline $55<P \leq 64$ & Rendah & $2.94 \%$ & $0 \%$ \\
\hline $0<P \leq 55$ & Sangat rendah & $2.94 \%$ & $0 \%$ \\
\hline \multicolumn{2}{|c|}{ Rata-rata } & 77.8 & 83.1 \\
\hline
\end{tabular}

Tabel 3 menunjukkan bahwa data hasil kemampuan berpikir kritis siswa setelah dilakukan tindakan untuk akhir siklus I berada pada kategori sedang dengan rata-rata 77.8 dan akhir siklus II berada pada kategori tinggi dengan rata-rata 83.1. Dari data tersebut, terdapat peningkatan kemampuan berpikir kritis siswa dari siklus I menuju siklus II.

Selanjutnya peneliti juga mengamati keterlaksanaan proses pembelajaran dengan model discovery learning melalui lembar kegiatan guru dan siswa. Adapun hasil yang diperoleh untuk tiap pertemuanpada siklus I dan siklus II disajikan pada Tabel 4.berikut:

Tabel 4. Keterlaksanaan Pembelajaran Siklus I dan Siklus II

\begin{tabular}{|c|c|c|c|c|c|}
\hline Siklus & Pertemuan ke- & Kegiatan & Terlaksana & $\begin{array}{c}\text { Tidak } \\
\text { Terlaksana }\end{array}$ & $\begin{array}{c}\text { Persentase } \\
\text { Keterlaksanaan }\end{array}$ \\
\hline \multirow[t]{6}{*}{ I } & \multirow[t]{2}{*}{$\mathrm{I}$} & Guru & 18 & 7 & \multirow[t]{2}{*}{$72 \%$} \\
\hline & & Siswa & 17 & 8 & \\
\hline & \multirow[t]{2}{*}{ II } & Guru & 22 & 3 & \multirow[t]{2}{*}{$88 \%$} \\
\hline & & Siswa & 20 & 5 & \\
\hline & \multirow[t]{2}{*}{ III } & Guru & 22 & 3 & \multirow[t]{2}{*}{$88 \%$} \\
\hline & & Siswa & 22 & 3 & \\
\hline \multicolumn{5}{|c|}{ Persentase Keterlaksanaan Siklus I } & $81 \%$ \\
\hline \multirow[t]{6}{*}{ II } & \multirow[t]{2}{*}{ I } & Guru & 20 & 5 & \multirow[t]{2}{*}{$80 \%$} \\
\hline & & Siswa & 20 & 5 & \\
\hline & \multirow[t]{2}{*}{ II } & Guru & 24 & 1 & \multirow[t]{2}{*}{$96 \%$} \\
\hline & & Siswa & 24 & 1 & \\
\hline & \multirow[t]{2}{*}{ III } & Guru & 25 & 0 & \multirow[t]{2}{*}{$100 \%$} \\
\hline & & Siswa & 25 & 0 & \\
\hline
\end{tabular}


Dari Tabel 4. di atas, diperoleh persentase rata-rata keterlaksanaan pembelajaran pada siklus I yaitu $81 \%$ dan siklus II yaitu $92 \%$. Data ini menunjukkan bahwa keterlaksanaan aktivitas pembelajaran sudah mencapai target pada kategori baik pada siklus I dan kategori sangat baik pada siklus II. Artinya, penerapan model discovery learning ini dapat meningkatkan kemampuan berpikir kritis siswa.

\section{E. Simpulan}

Hasil tes kemampuan berpikir kritis pada siklus I berada pada kategori sedang dengan rata-rata 77.8 dan dengan persentase ketuntasan $58.82 \%$, sedangkan pada siklus II berada pada kategori tinggi dengan rata-rata 83.1 dan dengan persentase ketuntasan $79.41 \%$.Selanjutnya hasil keterlaksanaan pembelajaran dengan model discovery learning berhasil dilaksanakan baik pada siklus I dan siklus II. Keterlaksanaan pembelajaran pada siklus I mencapai $81 \%$ dan pada siklus II mencapai menjadi $92 \%$.

\section{DAFTAR PUSTAKA}

Arikunto, S. (2006). Penelitian tindakan kelas. Jakarta: PT Bumi Aksara.

Elaine B. J. (2010). Contextual teaching and learning: Menjadikan kegiatan belajar mengajar mengasyikkan dan bermakna: terj, Ibnu Setiawan. Bandung: Kaifa.

Fitriawati, N. (2010). Penerapan model Pembelajaran berbasis masalah (problem based learning) dalam meningkatkan kemampuan berpikir kritis siswa pada mata pelajaran IPS terpadu kelas VIII di MTsN Selorejo Blitar. UIN Maulana Malik Ibrahim Malang.

Gagne, R.M. (1984). Kondisi belajar dan teori pembelajaran. Jakarta : Gramedia

Insani, S.U. (2018). Upaya meningkatkan rasa ingin tahu siswa terhadap pembelajaran matematika melalui model discovery learning dengan pendekatan saintifik pada siswa kelas X MIA 2 MAN Yogyakarta 1. Jurnal Pendidikan Tambusai, 2 (5), 1161-1171.

Kurniasih, I.\& Sani, B. (2014). Implementasi kurikulum 2013 konsep \& penerapan. Surabaya: Kata Pena.

Moore, Kenneth D. (2009). Effective instructional strategies. California: Sage Publications.

Permendikbud. (2014). Peraturan Menteri Pendidikan dan Kebudayaan Republik Indonesia Nomor 59 Tahun 2014 Tentang Kurikulum 2013 Sekolah Menengah Atas/ Madrasah Aliyah. Jakarta: Departemen Pendidikan dan Kebudayaan.

Sani, R.A. (2014). Pembelajaran saintifik untuk kurikulum 2013.Jakarta: Bumi Aksara.

Santrock, John W. (2011). Psikologi pendidikan (2nd ed.). Jakarta: Kencana

Sagala, S. (2010). Konsep dan Makna Pembelajaran. Bandung: Alfabeta.

Slameto. (1996). Teknik Evaluasi Pendidikan. Jakarta: P.T Raja Grafindo Persada.

Sugiyono, A. (2004). Pengantar Statistik Pendidikan. Jakarta: Grasindo Persada.

Suryosubroto. (2009).Proses Belajar Mengajar di Sekolah. Jakarta: PT Rineka Cipta.

Wijaya, C. (2010). Pendidikan Remidial. Bandung: Remaja Rosdakarya. 